\title{
Basin and petroleum system modeling in conjunction zone of the Alexander and Srednevasyugan anticlines and Ust-Tym depression, southeastern part of the West Siberian hydrocarbon province (Russia)
}

\author{
Alina Kosmacheva ${ }^{1}(\mathbb{D}) \cdot$ Marina Fedorovich ${ }^{1}(\mathbb{0})$
}

Received: 7 April 2020 / Accepted: 2 November 2020 / Published online: 18 November 2020

(c) The Author(s) 2020

\begin{abstract}
The paper is aimed at the basin and petroleum system modeling in the conjunction zone of the Alexander and Srednevasyugan anticlines and Ust-Tym depression during the Mesozoic-Cenozoic time. The exploration area is located in the southeastern part of the West Siberian hydrocarbon province. The present research primarily identifies the oil-window-entry time, maturity, generation points, generation power, and remaining potential of the Togur and Bazhenov source rocks. The Togur oil-window-entry time is $139.5 \mathrm{Ma}$. The Bazhenov oil-window-entry time is $99 \mathrm{Ma}$. Liquid hydrocarbons are extensively generated by the source rocks at the present time, since the Togur and Bazhenov Formations are found to be in the oil window. The significant amount of generated hydrocarbons is lost in migration processes. The source rock generation power and remaining potential are 1.1 and 1.5 billion tons of hydrocarbons, respectively.
\end{abstract}

Keywords Basin and petroleum system modeling $\cdot$ Source rock $\cdot$ Bazhenov formation $\cdot$ West Siberian hydrocarbon province

\section{Introduction}

To solve the problems associated with the evolution of a sedimentary basin and the prediction of oil and gas occurrence, modern technologies such as basin and petroleum system modeling are widely used (Baur et al. 2011; Hakimi et al. 2010; Kerimov et al. 2011; Makeen et al. 2016a; Makeen et al. 2016b). Comprehensive interpretation of geophysical, geological, and geochemical information can be essential theoretical background for the further identifying of burial and thermal histories of a basin (Al-Hajeri et al. 2009).

The West Siberian hydrocarbon province is the largest oil and gas basin in the world. Geographically, it is confined to the West Siberian Plane (Kontorovich et al. 1975). The petroleum industry and the geological exploration of the southeastern part of the province have lasted for more

Alina Kosmacheva

kosmachevaay@gmail.com

Trofimuk Institute of Petroleum-Gas Geology and Geophysics of the Siberian Branch of the Russian Academy of Sciences, Novosibirsk, Russia than 40 years (Kontorovich 2002). Most of the fields discovered therein have already reached the stage of declining production. It is obvious that the research of hard-to-recover reserves from complex and deep-seated deposits is a priority direction of the worldwide energy sector. It is the Chkalov oil and gas field that may be classified as an appropriate one. According to the oil and gas zoning, it is situated in the southeastern part of the West Siberian hydrocarbon province (Fig. 1).

Tectonically, the Chkalov field is located in the conjunction zone of the Alexander and Srednevasyugan anticlines and Ust-Tym depression (Fig. 2). There are the following reflection horizons in the exploration area: $\mathrm{F}_{2}, \mathrm{II}^{\mathrm{a}}$, III, IV, and V (Fig. 3). The reference surfaces divide the section of the sedimentary cover into four geoseismic complexes, namely Jurassic, Berriasian-Aptian, Aptian-Turonian, and Post-Turonian (Kontorovich 2002; Kosmacheva 2016). According to the structural geometry of the Bazhenov Formation top (reflection horizon $\mathrm{II}^{\mathrm{a}}$ ), the Chkalov anticline can be traced along the contour line of $-2510 \mathrm{~m}$ (Fig. 2).

There are three stages of tectonic activity in the exploration area, namely Early Jurassic, Early Cretaceous, and Late 


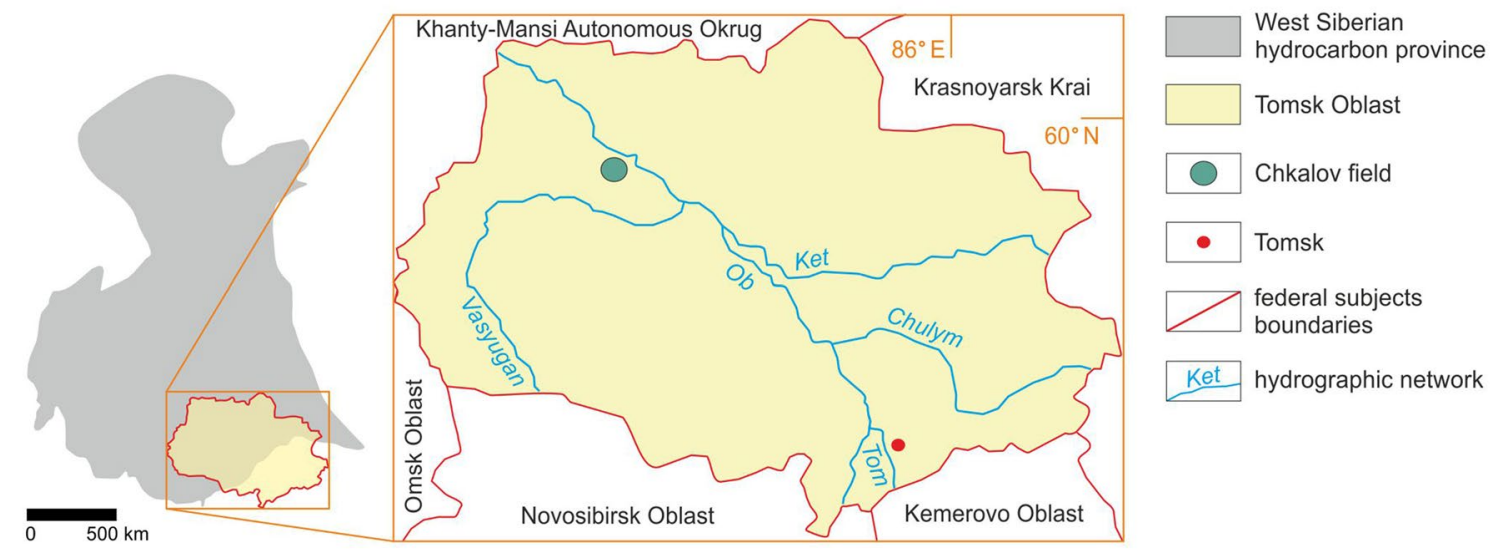

Fig. 1 Location map of the Chkalov field

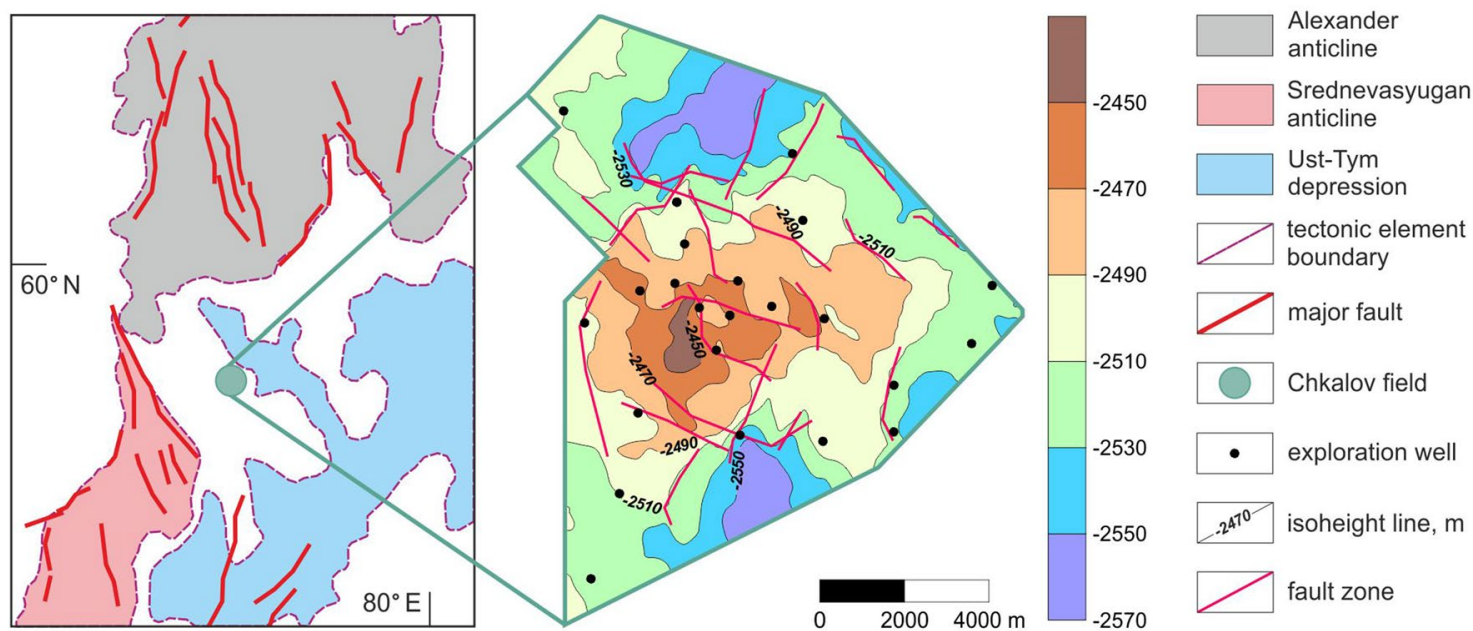

Fig. 2 Tectonic and structural setting of the Chkalov field according to the Bazhenov Formation top (after Kontorovich 2002; Kosmacheva 2016)

Cretaceous. All faults disappear in the Cenomanian rocks (Kosmacheva 2016).

The lithostratigraphic section of the Chkalov field is mainly represented by the interlayering of sandstones, siltstones, and claystones (Fig. 3). The Togur and Bazhenov Formations are source rocks (Kontorovich 2002). It is worth pointing out that the Bazhenov Formation is a unique group of rocks, where most of the Russian oil shale is concentrated. The $\mathrm{M}$ bed of weathering crust located in the contact zone between Paleozoic and Mesozoic rocks and the $\mathrm{Yu}_{1}$ sandstone member are known to be reservoirs (Danenberg et al. 2006; Gurari et al. 2005; Kontorovich 2002). The former is an oil and gas reservoir, while the latter contains only liquid hydrocarbons. The Togur Formation is a cap rock for hydrocarbon accumulations in the $\mathrm{M}$ bed of weathering crust. The Bazhenov Formation is considered to be a seal for hydrocarbon accumulations in the $\mathrm{Yu}_{1}$ sandstone member.
The Chkalov field was put into development in 1986. The complex structure of the deposits and the significant remaining potential of the source rocks currently enable the further exploration and production drilling to be carried out (Oilgasinform 2020; Parovinchak and Ezhova 2012). The actual framework of the field involves 24 exploration wells (Fig. 2). According to the Russian classification of deposits in terms of recoverable reserves, the Chkalov field can be treated as the medium size.

The basin and petroleum system modeling in the conjunction zone of the Alexander and Srednevasyugan anticlines and Ust-Tym depression is primarily aimed at the identification of the oil-window-entry time, maturity, generation points, generation power, and remaining potential of the source rocks. 


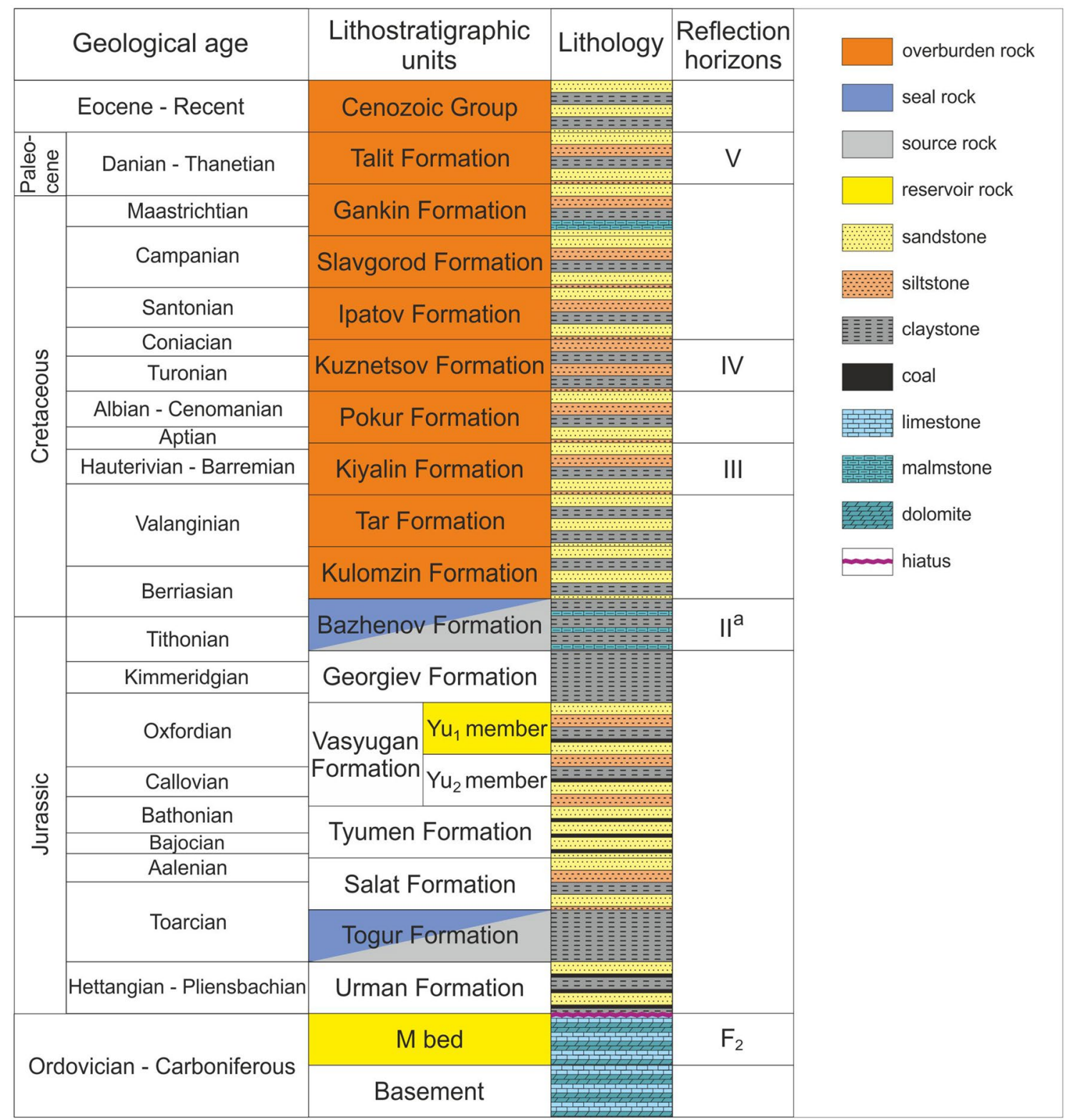

Fig. 3 Regional stratigraphy of the Chkalov field (after Arkhipov et al. 2002; Bakharev et al. 2001; Danenberg et al. 2006; Gaideburova et al. 2000)

\section{Methodology and input parameters}

Basin and petroleum system modeling applies mathematical algorithms to geoseismic, stratigraphic, lithological, geochemical, and other data to provide a valuable insight into the dynamics of a sedimentary basin and its fluids through time (Baur et al. 2011; Hakimi et al. 2010; Makeen et al. 2016a, b). The basin and petroleum system modeling in the conjunction zone of the Alexander and Srednevasyugan anticlines and Ust-Tym depression during the Mesozoic-Cenozoic time was carried out by using the PetroMod software (Schlumberger 2011). The platform allows the reconstruction of geological history and all processes in a basin to be implemented. The processes are integral to the deposition, subsidence, and transformation of sedimentary rocks and organic matter (Hantschel and Kauerauf 2009; Higley et al. 2006).

The research was based on the following input parameters:

(a) structure maps of principal reflection horizons;

(b) geological age and composition of the lithostratigraphic units;

(c) vitrinite reflectance $\left(R_{0}\right)$ with appropriate depth points; 
(d) total organic carbon (TOC), hydrocarbon indices (HI), and kerogen types of the source rocks;

(e) present-day reservoir temperatures.

The lithotypes default values of the PetroMod software were attributed to the lithostratigraphic units (Fig. 3). The Togur and Bazhenov Formations were primarily defined as claystone rocks variously enriched in organic matter of different genesis. TOC content was specified up to $7 \%$ in the Togur Formation and up to $12 \%$ in the Bazhenov Formation (Kostyreva 2005).

The source of the Togur organic matter was not only the phytoplankton and bacteria of freshwater lakes (Type I kerogen), but also terrestrial plant matter (Type III kerogen). The Bazhenov organic matter was mainly connected to marine phytoplankton (Type II kerogen) (Bogorodskaya et al. 2005; Burnham 2017; Kontorovich et al. 2013). The Togur and Bazhenov Formations were characterized by HI valued at 500 and $700 \mathrm{mg} / \mathrm{g}$, respectively (Kostyreva 2005).

\section{Modeling results}

The section presents the modeling results of tectonic development history, heat flow calibration, source rock maturity, quantitative assessment of hydrocarbon resources of the Chkalov field. Distribution of generation and migration densities of source rock hydrocarbons, oil-window-entry time of the source rocks, geological processes through time in the Chkalov field will be discussed in the following section.

The isopach maps of principal geoseismic complexes were obtained to determine the formation time of the potential trap structures (Fig. 4). The maps describe the changes in geoseismic complex thickness in the exploration area. The zones of increasing thickness correspond to the immersed sections and the least thickness coincided with the uplifted ones. There was an apparent tendency for paleo-structures to be on the rise. All the potential hydrocarbon traps of the Chkalov field formed during the Jurassic stage of development, they not undergoing significant changes up to the present.

To represent the natural conditions in the basin, thermal modeling was carried out by reference to the vitrinite reflectance, present-day surface heat flow (Duchkov et al. 2013), and present-day reservoir temperatures (Alipour et al. 2019; Hantschel and Kauerauf 2009; Higley et al. 2006; Makeen et al. 2016b; Osli et al. 2019). The heat flow calibration illustrated in Fig. 5 was based on the adequate agreement between the measured and modeled values of vitrinite reflectance and temperatures.

The modeling results after heat flow calibration involve the present-day temperature maps of the reservoirs (Fig. 6) and the organic matter maturity data of the source rocks.
The present-day temperature range in the $\mathrm{M}$ bed and $\mathrm{Yu}_{1}$ member varies from 102 to $110{ }^{\circ} \mathrm{C}$ and from 87 to $91{ }^{\circ} \mathrm{C}$, respectively. The highest values naturally conform to the depressions. The lowest values do to the positive structures (Fig. 2).

According to the common features of organic matter maturity in the West Siberian basin (Fomin 2011; Kontorovich 2004), the lacustrine and terrestrial deposits of the Togur Formation are in the oil window $\left(0.69-0.81 \% R_{0}\right)$. The maturity of the Togur source rock is connected to the most intense generation and the initial migration of hydrocarbons. The marine deposits of the Bazhenov Formation are involved in the oil window $\left(0.61-0.64 \% R_{0}\right)$. Early oil generation processes are expected to be in the Bazhenov source rock. The Kiyalin Formation, by comparison, is assumed to be immature $\left(0.33-0.37 \% R_{0}\right)$.

The quantitative assessment results of the Chkalov field hydrocarbon resources are provided below (Table 1).

The source rocks have generated 1.1 billion tons (BT) of hydrocarbons. The contribution of the Togur Formation is essential. 304.3 million tons (MT) of hydrocarbons have remained in the source rocks. 794.4 MT of hydrocarbons have been involved in the expulsion from the source rocks. 22.6 MT of hydrocarbons have accumulated in the reservoir rocks. 771.8 MT of generated hydrocarbons have been lost in migration processes. The source rock remaining potential is $1.5 \mathrm{BT}$.

\section{Discussion}

Liquid hydrocarbons are considered to be extensively generated by the source rocks at the present time, since the Togur and Bazhenov Formations are found to be in the central part and at the top of the oil window, respectively (Fig. 7). The Togur organic matter is estimated to generate from 70 to 260 (Type III kerogen) and from 4800 to 15,000 kilotons $/ \mathrm{km}^{2}$ (Type I kerogen) of hydrocarbons to date. The Bazhenov organic matter generates from 200 to 2100 kilotons $/ \mathrm{km}^{2}$. The deepest eastern and southeastern parts of the territory correspond to the major kitchen areas, where the organic matter of the source rocks has reached a high level of thermal maturity. The minimum values of generation densities are confined to the elevated central part of the territory (Fig. 2).

The distribution of hydrocarbon migration densities is due to the configuration of generation density isolines. The migration densities of the Togur hydrocarbons vary from 70 to 260 (Type III kerogen) and from 3000 to 14,000 kilotons/ $\mathrm{km}^{2}$ (Type I kerogen). The migration densities of the Bazhenov hydrocarbons vary from 100 to 2100 kilotons $/ \mathrm{km}^{2}$.

The events chart illustrated in Fig. 8 incorporates the chronological interrelation between the elements and processes of the petroleum systems in the Chkalov field. The 


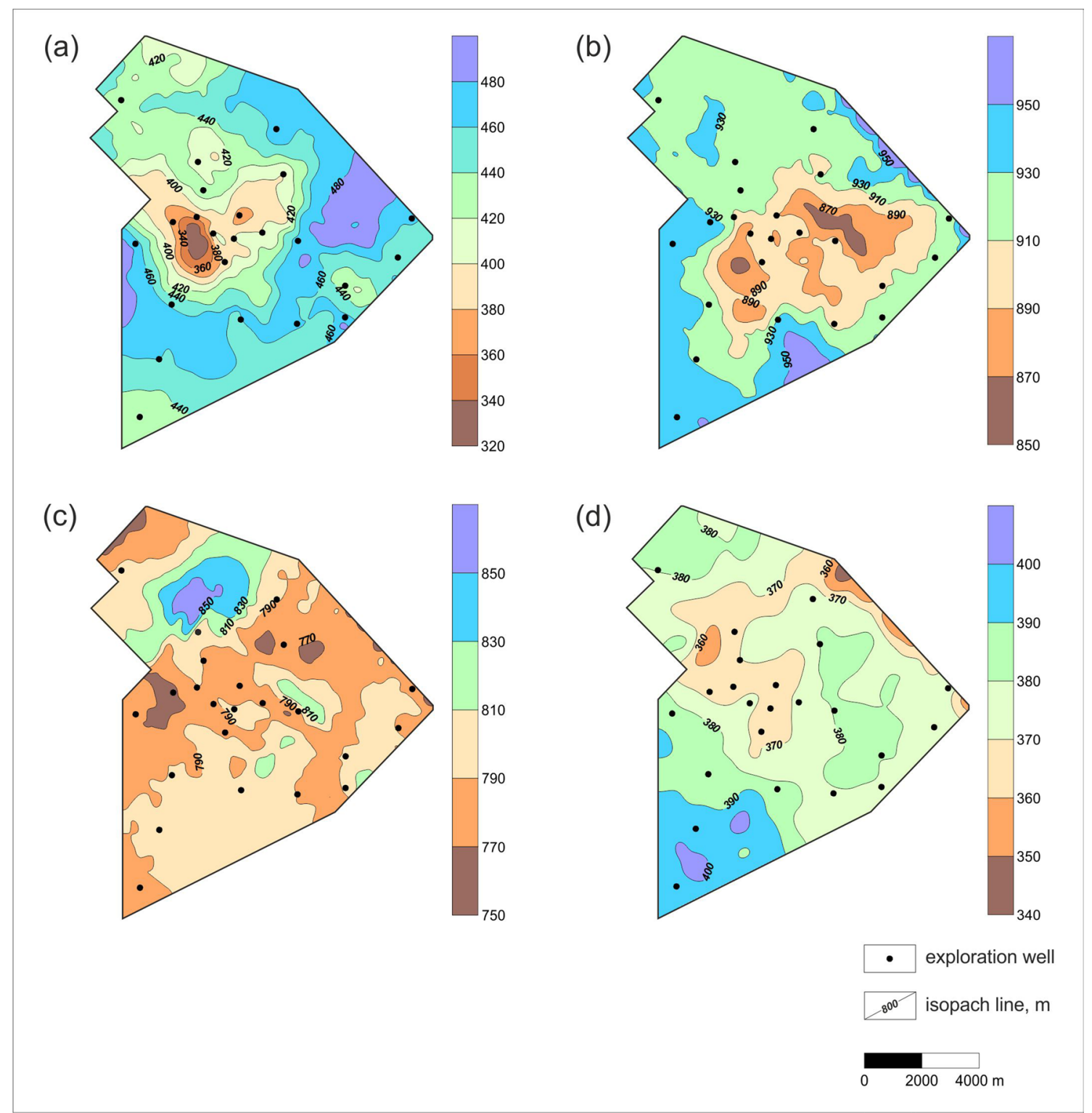

Fig. 4 Isopach maps of the geoseismic complexes in the Chkalov field: Jurassic complex (a); Berriasian-Aptian complex (b); Aptian-Turonian complex (c); Post-Turonian complex (d)

first petroleum system is related to the Togur source and seal rock. Hydrocarbons originated from the Togur Formation migrated into the $\mathrm{M}$ bed of weathering crust. The reservoir rock is formed during the late Paleozoic and early Mesozoic hiatus. The second petroleum system is related to the Bazhenov source and seal rock. Hydrocarbons originated from the Bazhenov Formation migrated into the $\mathrm{Yu}_{1}$ sandstone member. The overburden rocks overlying the Bazhenov Formation include Cretaceous and Cenozoic Groups.

Determining the timing of trap formation and generation, migration, and accumulation processes is one of the main goals of basin and petroleum system modeling (AlHajeri et al. 2009). The Togur Formation had not entered the oil window by beginning the sedimentation of the Bazhenov Formation (152.6 Ma); however, the main anticlinal structures, potential hydrocarbon traps, had already existed (Fig. 4). The Togur Formation had reached up to the oil window by ending the sedimentation of the Kulomzin Formation (139.5 Ma). Furthermore, there were initial gas generation processes with the contribution of terrestrial organic matter. The generated gas immediately migrated mainly through the fault zones. The Togur Formation subsiding to a depth of more than $1000 \mathrm{~m}$ had completely entered the oil window by ending the sedimentation of the Kiyalin Formation (119 Ma). There was an appropriate environment for the intense generation and migration of gas to be in progress. 


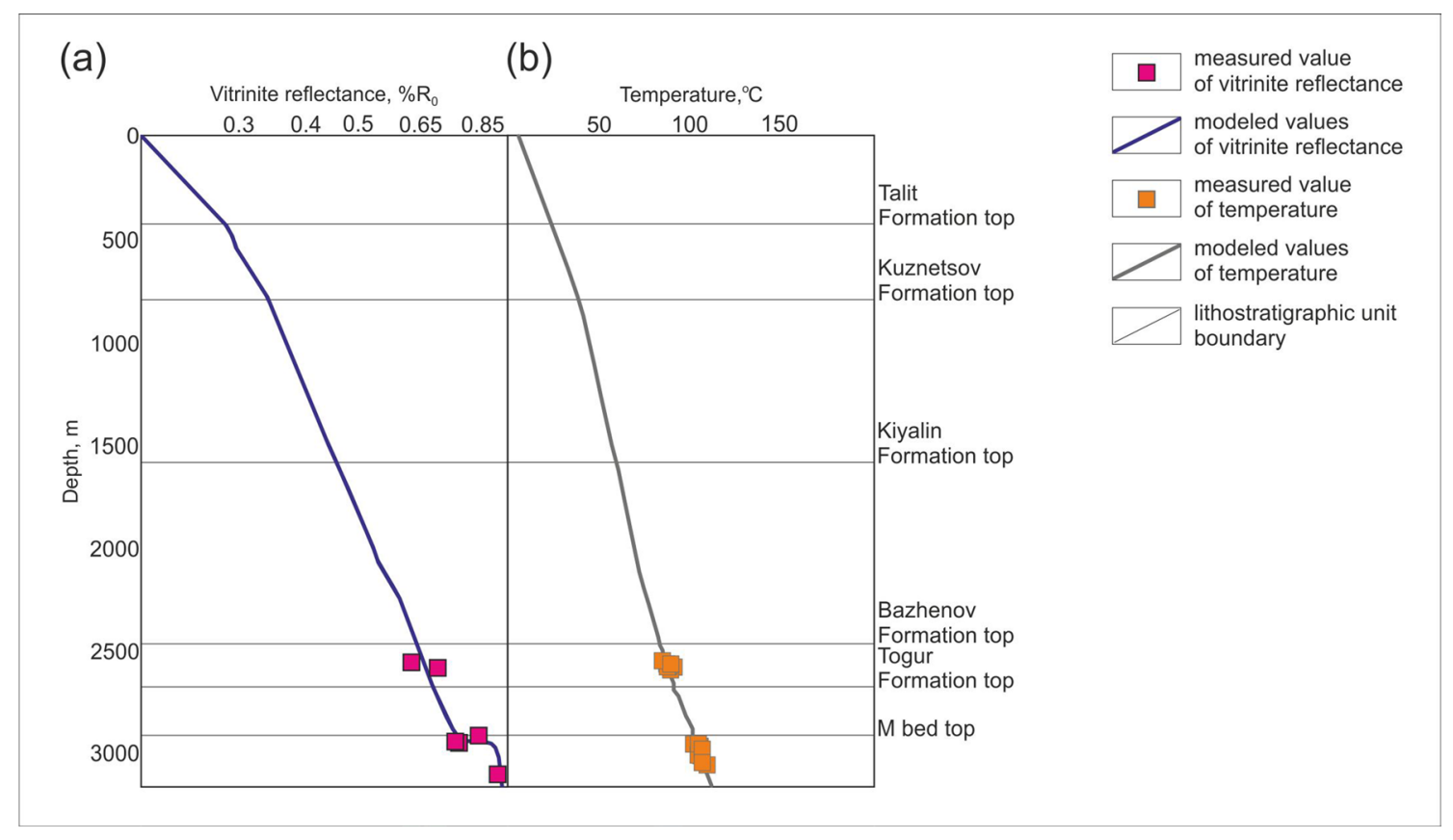

Fig. 5 Vitrinite reflectance (a) and temperature (b) calibration in a well of the Chkalov field

The deepest areas of the Bazhenov Formation had reached up to the oil window by ending the sedimentation of the Pokur Formation (99 Ma). There were initial oil generation and migration processes. The Bazhenov Formation subsiding to a depth of more than $2000 \mathrm{~m}$ had completely entered the oil window by ending the sedimentation of the Kuznetsov Formation (88.6 Ma). Hydrocarbon generation and migration processes entirely covered the exploration area.

An important concept in process timing in a petroleum system is the "critical moment." Generating source rock is estimated to be at a transformation ratio of $50 \%$. The four elements-source rock, reservoir rock, seal rock, and a sufficient amount of overburden must be in place before the critical moment (Al-Hajeri et al. 2009; Makeen et al. 2016b; Schlumberger 2011). The critical moment of the Togur petroleum system is supposed to be at the early Oligocene (31 Ma). The critical moment of the Bazhenov petroleum system has not yet occurred.

\section{Conclusions}

Basin and petroleum system modeling is a powerful tool providing an ample opportunity to build and evaluate the hydrocarbon history for potential source and reservoir rocks. The approach contributes a much more detailed and realistic representation of petroleum systems and the interconnection of its processes such as hydrocarbon generation, migration or trap formation.

The basin and petroleum system modeling in the conjunction zone of the Alexander and Srednevasyugan anticlines and Ust-Tym depression is primarily aimed at the identification of the oil-window-entry time, maturity, generation points, generation power, and remaining potential of the source rocks.

All the potential hydrocarbon traps are formed during the Jurassic stage of development. The Togur oil-window-entry time is $139.5 \mathrm{Ma}$. The Bazhenov oil-window-entry time is $99 \mathrm{Ma}$. The critical moment of the Togur petroleum system is at the early Oligocene ( $31 \mathrm{Ma})$. The critical moment of the Bazhenov petroleum system has not yet occurred. 
Fig. 6 Present-day temperature maps of the reservoirs in the Chkalov field: $M$ bed of weathering crust (a); $\mathrm{Yu}_{1}$ sandstone member (b)

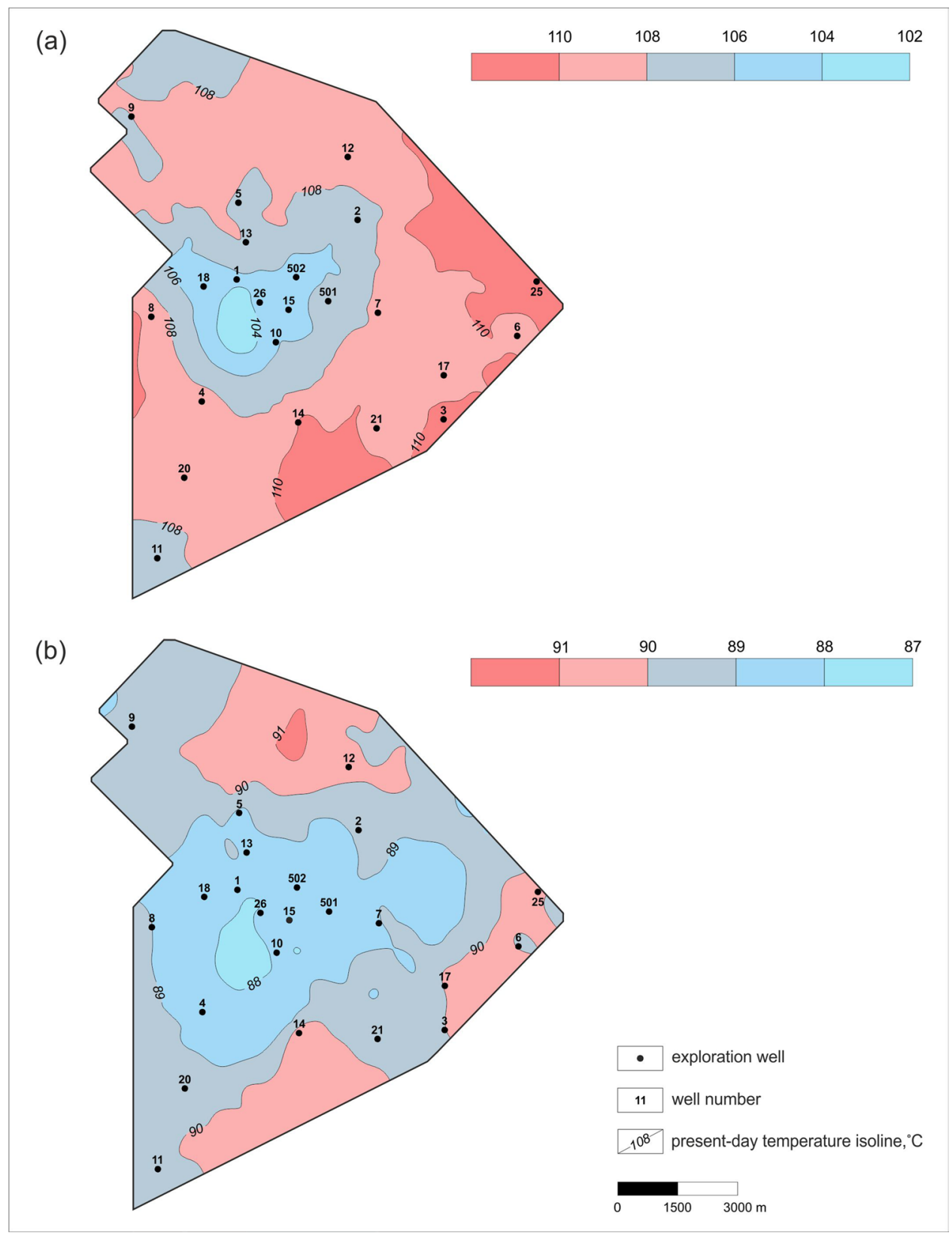

Table 1 Quantitative assessment results of the hydrocarbon resources of the Chkalov field

Generation balance, BT

Source rock balance, MT

Expulsion balance, MT

Reservoir balance, MT

Losses balance, MT

Remaining potential, BT

The values correspond to hydrocarbon equivalent
Liquid hydrocarbons are extensively generated by the source rocks at the present time. The Togur and Bazhenov Formations are found to be in the oil window. The eastern and southeastern parts of the territory correspond to the major kitchen areas. There is an appropriate environment for the hydrocarbon trapping to be in progress.

The generation power of the source rocks is $1.1 \mathrm{BT}$ of hydrocarbons, the Togur Formation contribution being essential. The remaining source rock potential is $1.5 \mathrm{BT}$. It is important to emphasize that the significant amount of generated hydrocarbons has been lost in migration processes. 
(a)

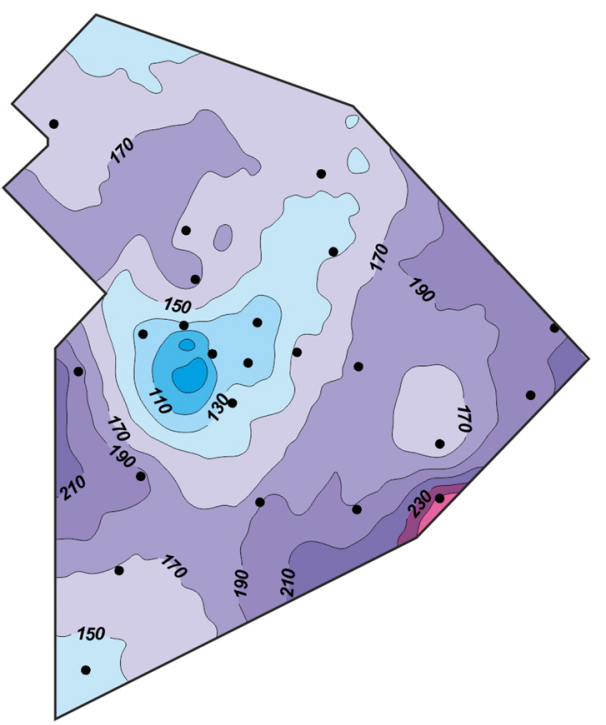

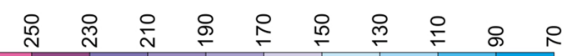

(c)

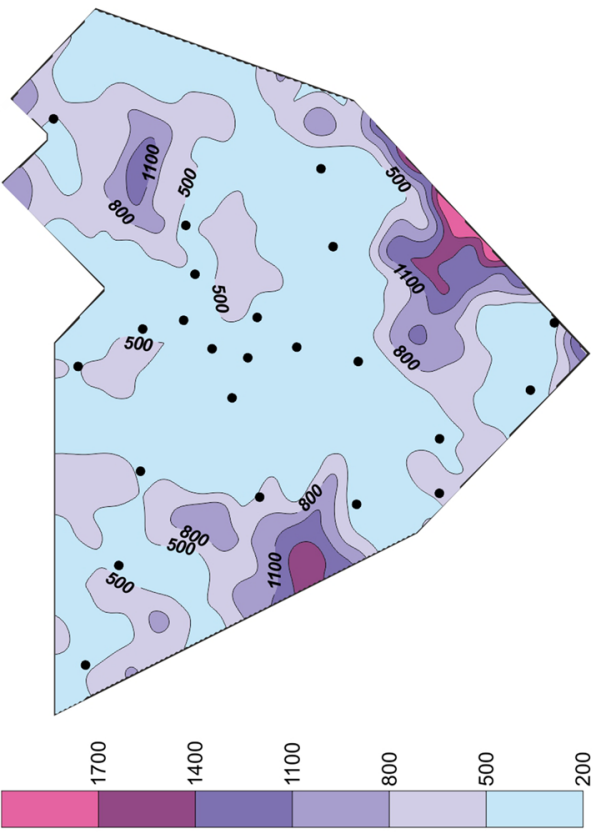

(b)

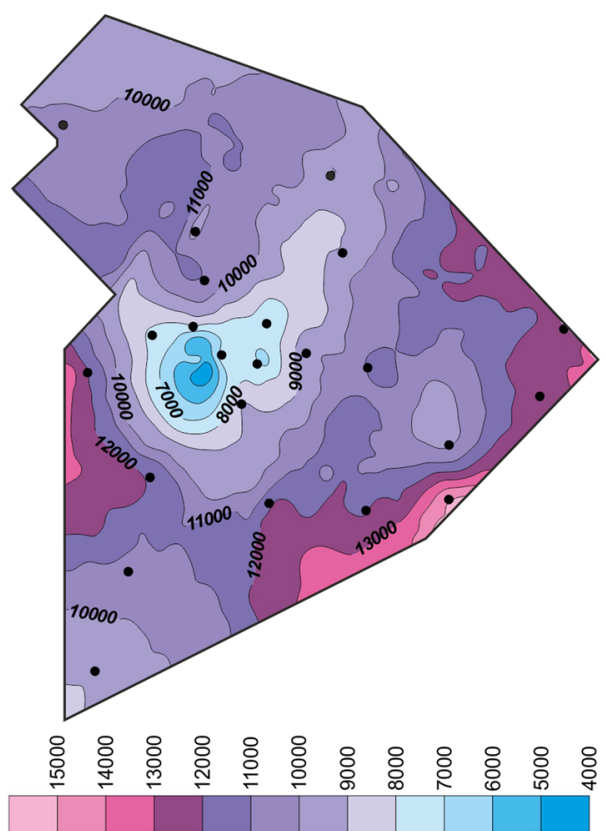

Fig. 7 Hydrocarbon generation density maps of the source rocks in the Chkalov field: Togur Formation (Type III kerogen) (a); Togur Formation (Type I kerogen) (b); Bazhenov Formation (c) 


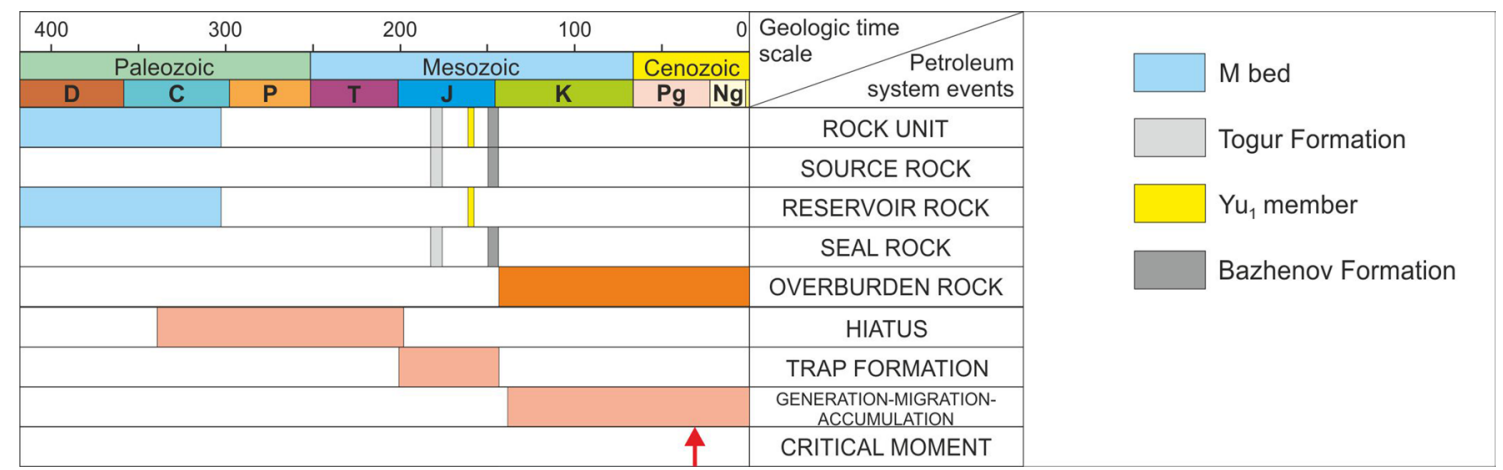

Fig. 8 Events chart depicting timing of the petroleum systems in the Chkalov field. Each of the colored horizontal bars represents the time span of an event

Acknowledgements The authors would like to thank to Alexander Fomin and Vladimir Kontorovich for the geochemical and geoseismic input data provided.

Funding The work was supported by the Project "Development of techniques for assessing resources, exploration and calculating reserves of hard-to-recover oil deposits in carbon-bearing carbonaceous-argillaceous-siliceous, carbonaceous and saline sand reservoirs", project number 0266-2019-0006.

\section{Compliance with ethical standards}

Conflict of interest The authors declare that they have no conflict of interest.

Open Access This article is licensed under a Creative Commons Attribution 4.0 International License, which permits use, sharing, adaptation, distribution and reproduction in any medium or format, as long as you give appropriate credit to the original author(s) and the source, provide a link to the Creative Commons licence, and indicate if changes were made. The images or other third party material in this article are included in the article's Creative Commons licence, unless indicated otherwise in a credit line to the material. If material is not included in the article's Creative Commons licence and your intended use is not permitted by statutory regulation or exceeds the permitted use, you will need to obtain permission directly from the copyright holder. To view a copy of this licence, visit http://creativecommons.org/licenses/by/4.0/.

\section{References}

Al-Hajeri MM, Al-Saeed M, Derks J, Fuchs T, Hantschel T, Kauerauf A, Neumaier M, Schenk O, Swientek O, Tessen N, Welte D, Wygrala B, Kornpihl D, Peters K (2009) Basin and petroleum system modeling. Oilfield Rev 21(2):14-29

Alipour M, Alizadeh B, Chehrazi A, Mirzaie S (2019) Combining biodegradation in 2D petroleum system models: application to the Cretaceous petroleum system of the southern Persian Gulf basin. J Pet Explor Prod Technol 9(4):2477-2486. https://doi.org/10.1007/ s13202-019-0716-8

Arkhipov SA, Babushkin AE, Volkova VS, Guskov SA, Kuzmina OB, Kulkova IA, Luvchuk LK, Mikhailova IV, Sukhorukova SS (2002) Stratigraphy of oil and gas basins of Siberia. Cenozoic of Western
Siberia, Siberian Branch of Russian Academy of Sciences, GEO, Novosibirsk

Bakharev NK, Belova EV, Dubatolov VN, Elkin EA, Izokh NG, Klets AG, Kontorovich AE, Krasnov VI, Peregoedov LG, Sennikov NV, Timokhina IG, Khromykh VG (2001) Stratigraphy of oil and gas basins of Siberia. Paleozoic of Western Siberia, Siberian Branch of Russian Academy of Sciences, GEO, Novosibirsk

Baur F, di Primio R, Lampe C, Littke R (2011) Mass balance calculations for different models of hydrocarbon migration in the jeanne d'arc basin, offshore Newfoundland. J Pet Geol 34(2):181-198

Bogorodskaya LI, Kontorovich AE, Larichev AI (2005) Kerogen: research techniques, geochemical interpretation. Siberian Branch of Russian Academy of Sciences, GEO, Novosibirsk

Burnham AK (2017) Global chemical kinetics of fossil fuels. Springer, Berlin

Danenberg EE, Belozerov VB, Brylina NA (2006) Geological structure and oil and gas content of the Upper Jurassic and Lower Cretaceous deposits in the southeast of the West Siberian plate (Tomsk region). Tomsk, Russia

Duchkov AD, Sokolova LS, Ayunov DE (2013) Electronic geothermal atlas of Siberia and Far East. Subsurface management. Mining. New directions and technologies for prospecting, exploration and development of mineral deposits. Geoecology 3:153-157

Fomin AN (2011) Catagenesis of organic matter and petroleum potential of Mesozoic and Paleozoic sediments in the West Siberian megabasin. Siberian Branch of Russian Academy of Sciences, GEO, Novosibirsk

Gaideburova EA, Devyatov VP, Dzyuba OS, Ilina VI, Kazakov AM, Meledina SV, Mogucheva NK, Nikitenko BL, Shurygin BN (2000) Stratigraphy of oil and gas basins of Siberia. Jurassic system, Siberian Branch of Russian Academy of Sciences, GEO, Novosibirsk

Gurari FG, Devyatov VP, Demin VI, Ekhanin AE, Kazakov AM, Kasatkina GV, Kurushin NI, Mogucheva NK, Sapyanik VV, Serebrennikova OV, Smirnov LV, Smirnova LG, Surkov VS, Sysolova GG, Shiganova OV (2005) Geological structure and oil and gas content of the Lower and Middle Jurassic deposits in the West Siberian hydrocarbon province. NAUKA, Novosibirsk

Hakimi MH, Abdullah WH, Shalaby MR (2010) Source rock characterization and oil generating potential of the Jurassic Madbi formation, onshore East Shabowah oilfields, Republic of Yemen. Organ Geochem 41(5):513-521

Hantschel T, Kauerauf AI (2009) Fundamentals of basin and petroleum systems modeling. Springer, Heidelberg

Higley D, Lewan M, Roberts L, Henry M (2006) Petroleum system modeling capabilities for use in oil and gas resource assessments. U.S. Geol Surv. https://doi.org/10.3133/ofr20061024

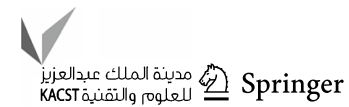


Kerimov VU, Hantschel T, Sokolov K, Sidorova MS (2011) Employment of the basin modeling technologies-program package PetroMod software into the educational processes of RSU of Oil and Gas named after I.M. Gubkin. Oil Gas Bus 4:38-47

Kontorovich VA (2002) Tectonics and petroleum potential of the Mesozoic-Cenozoic deposits in the southeastern parts of the West Siberian sedimentary basin. Siberian Branch of Russian Academy of Sciences, GEO, Novosibirsk

Kontorovich AE (2004) Analytical review on naftidogenesis theory. Siberian Branch of Russian Academy of Sciences, GEO, Novosibirsk

Kontorovich AE, Nesterov II, Salmanov FK, Surkov VS, Trofimuk AA, Ervie YuG (1975) Geology of oil and gas of the West Siberian sedimentary basin. NEDRA, Moscow

Kontorovich AE, Kontorovich VA, Ryzhkova SV, Shurygin BN, Vakulenko LG, Gaideburova EA, Danilova VP, Kazanenkov VA, Kim NS, Kostyreva EA, Moskvin VI, Yan PA (2013) Jurassic paleogeography of the West Siberian sedimentary basin. Russ Geol Geophys 54(8):972-1012

Kosmacheva AYu (2016) Geological structure, history of tectonic development and petroleum potential of the Chkalov field according to $2 \mathrm{D}$ and $3 \mathrm{D}$ seismic exploration and deep drilling. In: Proceedings of the 54th international students scientific conference. geology, pp 104

Kostyreva EA (2005) Geochemistry and genesis of Paleozoic oil in south-east of the West Siberian megabasin. Siberian Branch of Russian Academy of Sciences, GEO, Novosibirsk
Makeen YM, Abdullah WH, Pearson MJ, Hakimi MH, Ayinla HA, Elhassan OMA, Abas AM (2016a) History of hydrocarbon generation, migration and accumulation in the Fula sub-basin, Muglad Basin, Sudan: implications of a 2D basin modeling study. Mar Petr Geol 77:931-941

Makeen YM, Abdullah WH, Pearson MJ, Hakimi MH, Elhassan OMA, Hadad YT (2016b) Thermal maturity history and petroleum generation modeling for the Lower Cretaceous Abu Gabra Formation in the Fula Sub-basin, Muglad Basin, Sudan. Mar Pet Geol 75:310-324

Oilgasinform (2020) Chkalov field. Independent Oil and Gas Portal. https://oilgasinform.ru/science/fields/chkalovskoe/. Accessed 5 Oct 2020

Osli LN, Shalaby MR, Islam MA (2019) Hydrocarbon generation modeling and source rock characterization of the Cretaceous-Paleocene Taratu Formation, Great South Basin, New Zealand. J Pet Explor Prod Technol 9(1):125-139. https://doi.org/10.1007/s1320 2-018-0511-y

Parovinchak KM, Ezhova AV (2012) Geology features, substantiation of the integrated development of oil and gas condensate fields in the Tomsk region. Sci Tech Bull OJSC NK Rosneft 1:14-17

Schlumberger (2011) PetroMod petroleum systems modeling. Schlumberger Information Solutions, Houston

Publisher's Note Springer Nature remains neutral with regard to jurisdictional claims in published maps and institutional affiliations. 